\title{
THE IMPORTANCE OF FACTORS AFFECTING THE ENTRY OF ENTREPRENEURIAL SUBJECTS TO ORGANIC FARMING IN THE CZECH REPUBLIC
}

\author{
Hana Stojanová1, Veronika Blašková2 ${ }^{2}$ Michaela Lněničkováa \\ ${ }^{1}$ Department of Management, Faculty of Business and Economics, Mendel University in Brno, Zemědělská 1, \\ 61300 Brno, Czech Republic \\ ${ }^{2}$ Department of Statistics and Operation Analysis, Faculty of Business and Economics, Mendel University in Brno, \\ Zemědělská 1, 61300 Brno, Czech Republic
}

\begin{abstract}
STOJANOVÁ HANA, BLAŠKOVÁ VERONIKA, LNĚNIČKOVÁ MICHAELA. 2018. The Importance of Factors Affecting the Entry of Entrepreneurial Subjects to Organic Farming in the Czech Republic. Acta Universitatis Agriculturae et Silviculturae Mendelianae Brunensis, 66(4): 1017-1024.

The aim of the article is to identify the key factors influencing the entry of entrepreneurial subjects into the sphere of organic farming in the Czech Republic. Primary data for the research was obtained from a questionnaire survey carried out in 2016 through an internal communication system of the PRO BIO Association, comprising 481 operators in the field of organic farming in the Czech Republic.

The research questions mainly concerned the reason for entering the sphere of organic farming, and what influenced this decision, the motivation of entrepreneurs to stay in organic farming and what could possibly be the reason for their departure from this sector of business. Another part of the research questions related to the knowledge about organic farming in the establishment of their business. a combination of factors that are important in deciding on entry into the industry and subsequent stay was found.
\end{abstract}

Keywords: organic agriculture, biodynamic agriculture, dendrogram, entering of entrepreneurial entities into organic agriculture field, Chí-square test, cluster analysis, personal motivation

\section{INTRODUCTION}

The orthodox model of agriculture has been aiming, with a help of increasing input into a productive process e.g. doses of fertilizer, a vast chemical protection of plants and its technical equipment, to achieve the highest production possible. From this aspect, conventional agriculture increases the pesticide demand, industrial fertilizes and more efficient agricultural machinery, which inevitably results in negative impact on ecological stability (Pimentel et al.,2005; Woese et al.,1997; Rembialkowska, 2007). With the formation of different ecological unions, the awareness of chemical substance harmful effects on environment and on body system raised (Vetter et al., 1987; Liebman et al.,
2001; Steiner, 2004; Heimler et al., 2009; Kuminoff, 2010). Literature of fact introduces the whole stream of economical and environment friendly agriculture (e.g. biodynamic agriculture, alternative agriculture, organic farming), but the official name in Czech and EU, is eco farming. In this article, there are terms of biodynamic agriculture and eco farming, symbolizing the agriculture, succeeding within the nature without chemical substances, pesticides, soil regulators and other chemical substances.

Bio agriculture is a demanding branch not only on the level of knowledge, time and economy, but also for its ethical and social approach (Mala, 2011; Bellon and Penvern, 2014). Currently the focus is on biodynamic agriculture and is influenced 
by an effort for the landscape preservation and improving the environment compare with the conventional intensive agriculture, also by a strength of European donation programmes and by the target profit (Kroupova and Maly, 2010; Pechrova, 2014; Sejnohova et al., 2015). a wide spectrum of scientific studies and literature sources (Tuomisto et al. 2012; Mondelaers, 2009; Burton et al., 1999) gives the reasons of entry into this branch. The main intentions have economic character, completed with the environmental and ethical motives (Greene et al., 2009; Chouinard, 2008; Brekke et al., 2003; Mzoughi, 2011).

The BIO or ECO label of eco-products has become an important indicator for certified, highly valuable foodstuffs, produced by a considerate land cultivating, plant growing and animal farming, according to welfare (Spoolder, 2007; Heimler et al., 2011; Liebman, 2001). According to current observations, the complex value exceeds the valuation of agriculture importance for the society. It involves economic, social and ecologic target groups of agriculture.

\section{Eco-farming in Czech Republic}

Biodynamic agriculture was introduced by Rudolf Steiner in 1924 (Steiner, 2004). First mention about eco-farming in Czech Republic is in literature of fact, dated to 1990, where MZe CR, Libera association and PRO-BIO Union established the whole system. In the era of donation slump (1993-1996), two of five unions have been reduced and MZe Czech Republic paid attention to legislative amendment, methodical regulations and to unification. Methodical guide of eco agriculture cj. 655/93-340 dated to 22. june 1993 has been in effect in Czech Republic from 1993. Only inner union guidelines of eco farmers existed up to this year. The European Union started the accreditation process of eco farming and the trademark of bio products has been determined (Zidek, 1999). Eco farming in Czech Republic comes under the Czech Ministry of Agriculture surveillance and every eco farmer, using the label $\mathrm{BIO}$ has to be registered, according to the law nr. 252/1997Sb., of eco farming (Ministry of Agriculture,
2014, Ministry of Agriculture, 2015). The PRO-BIO Association is a national civilian union which associates eco farmers, processors, wholesalers, advisers, schools, research facilities, bio-product consumers and eco farming friends (PRO-BIO, 2016). The law for eco-farming nr.242/2000Sb. identifies the plant and dairy production in organic farming, it implements the idea of 'eco-farm', which is understood as independent and closed economic unit, covering buildings and lands. The target of clear and intelligible eco-farm demarcation is a reasonable separation of eco-farming from another agricultural production of businessmen and its clear identification, proceeding from a Law nr.242/2000 Sb., for ecological farming. The IFOAM, International Federation of Organic Agriculture Movements is the worldwide umbrella organization for the organic agriculture movement. This federation represents 800 affiliates in 115 countries worldwide. IFOAM EU represents more than 340 members of the European Free Trade Association (IFOAM, 2016).

The aim of the article is to identify key factors influencing the entry of business subjects into Biodynamic agriculture in Czech Republic. The research was mainly related to the reason why to enter the organic farming business and what was the key factor and motivation of entrepreneurs to maintain in this branch and what could possibly cause the withdrawal from this business field.

\section{MATERIALS AND METHODS}

The questionnaire was chosen to collect the primary data. Electronic questionnaires were sent via inner communication system to members of union 481 PRO-BIO doing business in this matter in Czech Republic longer than a year. The respond 's rate was $22.04 \%$. The questionnaire contained 20 questions: 4 of them related to identification, 9 of them related to general business in eco-farming, 5 of them dealt with the entry into this branch and 2 questions were related to maintaining in this business. Some of the questions were not answered by all 106 respondents but all

I: Number of registered entities in organic farming

\begin{tabular}{lcccc}
\hline & $\mathbf{2 0 0 0}$ & $\mathbf{2 0 1 4}$ & $\mathbf{2 0 1 5}$ & $\mathbf{2 0 1 6}$ \\
\hline Organic Farmers & 563 & 3885 & 4115 & 4243 \\
Soil land - share for agricultural land & $3.86 \%$ & $11.72 \%$ & $11.74 \%$ & $12.03 \%$ \\
\hline
\end{tabular}

Source of data: PRO-BIO 2016

II: Soil fund structure in organic farming

\begin{tabular}{lcccc}
\hline & $\mathbf{2 0 0 0}$ & $\mathbf{2 0 1 4}$ & $\mathbf{2 0 1 5}$ & $\mathbf{2 0 1 6}$ \\
\hline Arable land & 12.44 & 11.4 & 13.05 & 13.12 \\
Permanent grassland & 86.72 & 83.54 & 82.37 & 82.65 \\
Permanent cultures & 0.32 & 1.57 & 1.38 & 3.2 \\
Other areas & 0.52 & 3.47 & 3.01 \\
\hline
\end{tabular}

Source of data: PRO-BIO 2016 
the respondents answered the key question related to measures, influencing the entry of business interests into the eco farming. This is the reason why all the questionnaires are valid. Authors divided the questionnaire results into subchapters according to these four subjects. The key factors influencing the decision to enter the eco farming business and their importance was identified, hypotheses of analysis results were verified and utilized in Statistica programme version 12 with a help of a chart method. The influence of factors was evaluated according to the relative frequency and $\mathrm{p}$-values, carried out in a test of independence. The 5\% level of importance has been chosen to verify Chi square test, and compared with the given p-value. The clustering method has been used to find the group of factors, important for their producers to influence the entry into the eco-farming sector. The Ward method had the best results.

\section{The respondents 'characteristics}

The $76 \%$ of men and $22 \%$ of women aged between 31 and 60 years took part of the questionnaire, $2 \%$ of respondents did not answer this question. The highest achieved education represents $1 \%$ of basic education, 19\% of respondents represent high school education with the vocational certificate, college education with leaving exam certificate represents $39 \%$ of respondents, higher scholar education represent $4 \%$ of respondents and academic education represent $37 \%$ of all respondents. $63 \%$ of all respondents have education related to agriculture in some way and $14 \%$ of respondents have education directly related to eco-farming. $95 \%$ people doing business in eco-farming longer than 3 years, which is influenced by legislation factor, when entering the eco-farming sector and by the length of conversion period. Respondents worked within the sector of plant and dairy production, where $15.69 \%$ of these respondents also focused on another sector of business, which is organic food production, agro tourism, accommodation services or organic food sale. $50 \%$ of all respondents worked in the plant and the dairy sector of production, and $50 \%$ of respondents worked in either of the production sectors. $44 \%$ of businessmen employ $1-5$ people, 9\% employ 6-15 people, 6\% employ 16-25 people. Nearly $39 \%$ of people in business do not have any employees (only family members) and $2 \%$ of respondents employ more than 26 people. The whole $70 \%$ of respondents employ only family members and friends, $27 \%$ of respondents employ people with no family relation, $3 \%$ of respondents employ both the categories. The greater number of respondents uses the combination of ways to finance the eco-farming. 89\% of respondents use own profit, $70 \%$ use Czech Republic or EU donation programmes as a financing source. Only $8 \%$ of respondents use the $\mathrm{PRO}-\mathrm{BIO}$ union subsidies, $65 \%$ of respondents use preferably long term mortgages to short term ones. Only $4 \%$ of respondents use other source of funding as profits from another business, loans from independent people and a main working income outside the eco-farming business. $75 \%$ of respondents find their business profitable even if they use funds or loans.
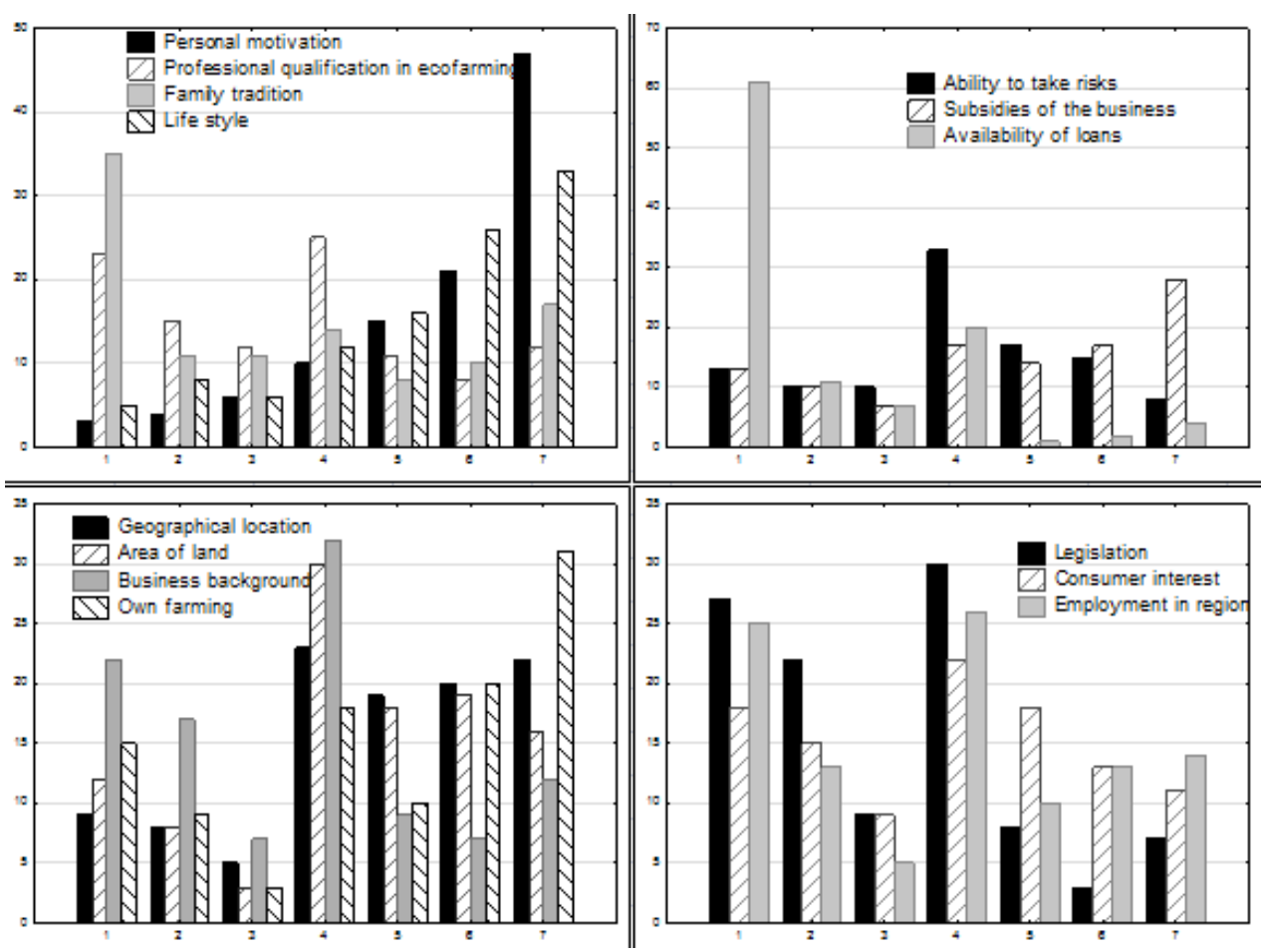

1: Frequency of responses 


\section{RESULTS}

$26 \%$ of respondents had an experience within this branch when starting the eco-farming business, $67.9 \%$ of respondents already had an experience with agriculture (although just conventional) and had a space for the business. The reason for a different way of farming or starting this business was mainly compromised by economic factors (funding programmes, better product profit, and higher demand) and by personal factors which was disapproval with this orthodox way of farming and a call for its simplifying (not necessarily register the chemical substances and save time when avoiding the spraying) and also by the interest for an environment, a nature, a better animal treatment and plant cultivation. Factors that influenced start of the business matter into the eco-farming sector. Respondents evaluated 14 features on a 7 point scale. Number one, (the lowest number on the scale) showed a very little significance of factor influence when making decision to enter the biodynamic agriculture, number 4 showed the neutral factor influence and number 7 showed a very important factor influence. Respondents had a possibility to present further factors and based on those, they made decision. Examined features were divided into groups according to the economic and personal focus, the business location and socio-legislative factors. Frequencies of responses of all factors are in Fig. 1.

\section{Economic factors}

The ability of risk taking, gaining funds and credit availability was included amongst economic factors, relating to a financial frustration to start the eco-farming business, especially with the investment threat due to nature forces. Respondents did not find this factor important. $55 \%$ of respondents found the factor of functional funding program in CR and EU important. The factor of credit availability was evaluated as unimportant. $90 \%$ of respondents, who found the fund factor important, mentioned they would consider staying within the eco-farming business, if there was a change of funding.

\section{Personal factors}

A personal motivation of entrepreneur, professional qualification in eco-farming, life style, and family tradition was included amongst personal factors.

More than $85 \%$ of respondents had a personal factor of motivation on the scale from 4 to 7 points, which shows a great importance when deciding to start the eco-farming business. Family tradition has been found as an unimportant factor. Life style together with eco-farming has been rated as a very important factor, which is visible in the chart. $70 \%$ of respondents rated the life style factor on the scale of points from 4 to 7.

\section{Factors of business location}

Factors of business location covered a geographical building position, land size, equipment, and support of business and own farm. Respondents gave an important role to a geographical position in terms of pastures access, fertile soil for cultivating, water supply and suitable micro climate $160 \%$ of respondents rated the importance on the scale of points from 4-7). The size of land has been rated as a very important factor, especially for farmers dealing with dairy production. If we compare the result of importance to farmers in testing who deal with dairy production with those, who only deal with plant production, we get the important differential ( $p$-value is 0.001). Equipment and business support is a neutral factor and does not influence any decision about starting the business.

\section{Socio-legislative factors}

Legislation, entry barrier, interest of consumers for organic food, working within region and professional qualification belongs to a group of socio-legislative factors. Respondents rated the professional qualification as unimportant factor together with legislation. Respondents also answered, if there were more administrative and legislative requirements, they would consider leaving this business. $50 \%$ of respondents rated the legislation question between 1 and 2 and $30 \%$ of respondents answered with value 4 (neutral). If we start testing respondents and we exclude those with the neutral answer, we can see the important differential in answered questions 1-3 and 5-7. Based on testing we can say, the percentage of respondents, who do not find the legislation interesting, is higher than percentage of those, who can see it as a problem. 99\% of respondents answered the question about remaining in eco-farming and only $4.7 \%$ answered, they consider leaving this business. The main reason to leave was the decrease of funding or funding programmes, too much supervision and bureaucratic strain. The interest of consumers for organic food was important for those respondents who sell their products directly or by box sale. Working within region was not an important factor.

Tables with basic statistic characteristics, arithmetic average, median and modus show the evaluation of individual criterion on the scale which has affected the entry of respondents into eco-farming. For example the personal motivation factor has reached the highest point on the evaluation scale and therefore this factor can be found as most important. On the other side, mortgage availability reached the lowest point and therefore the factor is not important at all. The scale value identifies degree of importance, which was voted most by respondents. As stated previously, number 1 symbolizes factor that is least important when deciding to start the business and is only apparent at (mortgage availability and family tradition). Number 4 is in the middle of the scale 
and it rates factors neutrally, neither important nor unimportant. Eight factors are rated with this value, which is $57 \%$ of observing items. The highest value is number seven on the scale which represents a very important factor and we can find it in these four criteria (personal motivation, funds of Czech republic. and EU, own farm and lifestyle).
The scale of factor importance, influencing the business establishment is built upon modus, the statistical value of individual criteria and their significance has been measured in the questionnaire (Tab. III).

According to this value, we can divide influence of factors into three groups: very important, insignificant and neutral. These three groups

III: Basic statistic criteria

\begin{tabular}{|c|c|c|c|c|}
\hline Criterion & Mean & Median & Modus & Scale of factor \\
\hline Lifestyle & 5.23 & 6 & 7 & Very important \\
\hline Own farming & 4.73 & 5 & 7 & Very important \\
\hline Subsidies of the Czech Republic and the EU & 4.62 & 5 & 7 & Very important \\
\hline Consumer interest in organic products & 3,85 & 4 & 4 & Neutral \\
\hline Professional qualifications & 3.55 & 4 & 4 & Neutral \\
\hline Ability to take risks & 4.02 & 4 & 4 & Neutral \\
\hline Employment in the region & 3.74 & 4 & 4 & Neutral \\
\hline Availability of loans & 2.17 & 1 & 1 & Insignificant \\
\hline
\end{tabular}

Source: own elaboration

IV: Dividing of neutral factors

\begin{tabular}{cc} 
IV: Dividing of neutral factors & Rather important \\
\hline Rather insignificant & Ability to take risks \\
Professional qualifications & Geographical location of the business \\
Legislation & Area of land \\
Consumer interest in organic food & \\
Work experience in the region & \\
\hline
\end{tabular}

Source: own elaboration

V: p-value for test independence (factor and motive for entering eco-farming)

\begin{tabular}{lc}
\hline \multicolumn{1}{c}{ Factor name } & p-value \\
\hline Personal motivation & 0.823 \\
\hline Professional qualifications in organic farming & 0.601 \\
\hline Ability to take risks & 0.464 \\
\hline Geographic location & 0.673 \\
\hline Area of land & 0.925 \\
\hline Subsidies (Czech Republic, EU) & 0.469 \\
\hline Business background & 0.656 \\
\hline Legislation (national, international) & 0.871 \\
\hline Consumer interest in organic farming products in the area & 0.468 \\
Loans & 0.999 \\
\hline Family tradition & 0.215 \\
\hline Own economy & 0.430 \\
\hline Lifestyle & 0.669 \\
\hline Work experience in the region & 0.305 \\
\hline Source: & \\
\hline
\end{tabular}

Source: own elaboration 


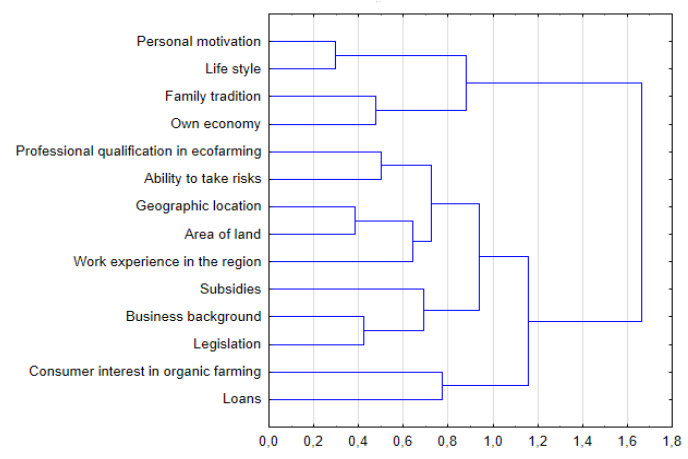

2: Dendrogram-Ward's method

represent points on a three point scale of factor importance. If neutral criteria take to account mean and relative frequency, we can include them amongst rather important or rather unimportant criteria. Values of mean of value less than four are rather unimportant and values above number one are rather important criteria for deciding of entry the eco-farming business (table IV).

We investigated further, how individual factors on the scale of importance influence people when starting the eco-farming business. In Tab. V is p-value for test independence. Null hypothesis shows no relation between the value of given factor and the motive for entering the eco-farming business.

Looking at the Tab. V, we can see the result for all tests and we do not reject Null hypothesis what means that, the relation between given factor and motivation of starting business was not convincing. Therefore we have dealt with the possibility of finding relation of factors which influences the motivation of entering business.

The four or five factor groups are recognizable from the dendrogram (fig. 2). The amount of groups has been also proved on the base of factor analyses, which prefers four groups.

Personal motivation, lifestyle, family tradition and own farm belongs to first cluster. This cluster could be called as a producer's persuasion about importance of bio farming to lead a better lifestyle. Professional qualification, ability of risk taking, geographical position of business, size of land and working within region belong to second cluster. This cluster could be called as operator's disposition for a good usefulness in bio-farming sector. The third cluster is constituted of legislation, business support and funding possibility. These factors could be found as an influence of government and state. There is an interest of consumers and mortgage in the last cluster that is just economical section of business. It is quite clear there always have to be several factors linked together to motivate a new producer.

\section{DISCUSSION}

Organic farming can be characterised by increasing amount of soil with more organic content using natural organic fertilizers produces unpolluted products and provides new guidelines in agriculture through diversification in a general context of protecting the environment and promoting sustainable agriculture development (Stanciu, 2008). The interest in the organic farming started in the highly developed countries as a result of social awareness about the negative side effects of the highly intensive agricultural production. Organic farming responds to the demand for organic food and support for organic farming. The biggest areas of agricultural land utilised for organic farming are in the richest countries of Western Europe countries. Also the spending on organic food per capita in these countries is the biggest (Komorowska, 2014). As of the end of 2015 the Organics International declare that 2.5 percent of the agricultural area was organic in Europe, 6.2 percent within European Union with 270000 producers. Twenty-five percent of the world's organic land is in Europe. The countries with the largest organic agricultural areas were Spain with almost 2 million hectares, Italy with 1.5 million hectares and France with 1.4 million hectares. The largest market for organic products in 2015 was Germany, with retail sales of 8.6 billion EUR, followed by France with 5.5 billion EUR and then UK market with 2.6 billion EUR (Jula Willer, Lernoud, 2017). Potential farmers can evaluate the idea of organic farming as more profitable but contrary to the idea of organic farming as potentially more risky as suggested by Acs et al. (2009) among others, followed by the apprehension of weeds and insects as potential sources of business failure (Khaledi et al. 2010). The opinion that the organic food prices are higher than the standard food may be opposed by Flaten et al. (2010) that too low organic price premiums are one of the main reasons for opting out of organic farming in Norway. Literal sources (Chouinard, 2008, Greene et. al, 2009, Mondelaers, 2009, Mzoughi, 2011, Tuomisto et al. 2012) reason the change from orthodox way of farming to ecological one with financial motives, especially by reaching funds. Czech eco farming funds are stabilized and are the key factor during conversion period. Into this period that cannot exceed 6 years in Czech can be included only soil together with cultivated plants 
without chemical treatments for the time of 6 months. The process of conversion comes under eco-farming law nr. 242/2000 and is a subject to an inspection twice a year.

The conversion goes along with changes in business which is loss of profit caused by starting the ecological system, lowering returns and quantity of animals on a farm, changing market plants. This loss is not compensated with raising prices of eco-products because leaving business does not correspond with this indication. This statement can be supported by the argument stressed in several studies of the conversion period and would pose a substantial source of risk and a potential barrier for a farmer considering converting (Acs et al. 2007, Kerselaers et al. 2007, Lampkin, Padel 1994). An often used key link in literature between funds and eco-farming business was not confirmed in conditions of biodynamic agriculture in Czech Republic.

\section{CONCLUSION}

The $78.3 \%$ of respondents find personal motivation important and $70.8 \%$ of respondents find lifestyle important. People starting eco-farming business, have $67 \%$ of experience with orthodox agriculture. Size of land, own farm and geographical position were indicated as very important factors. The most surprising is the evaluation absence of farmland quality. Over $75 \%$ of respondents use subsidies of Czech Republic and EU as a source of financing and $76.4 \%$ of respondents use one of important factors, $76.4 \%$ use subsidies of CR and $74.5 \%$ of respondents use subsidies of EU. Unimportant factors: support of business, professional qualification, family tradition, working within region, ability of risk taking, interest of consumers for local organic products. Within other factors, legislation is the unimportant factor influencing the start of eco-farming business however it is the important factor when leaving the business.

The organic development and production plays a key role in the society, as creates a specific market responding to consumer demand for organic products, as well as delivers public goods, job creation and the stimulation of the organic food sector and rural economies.

\section{REFERENCES}

ACS, S., BERENTSEN P.B.M.,DEWOLFM.etal.2007.Comparison of conventional and organic arable farming systems in the Netherlands by means of bio-economic modelling. Biological Agriculture $\sigma$ Horticulture, 24: 341-361.

ACS, S., BERENTSEN P., HUIRNE, R. et al.2009. Effect of yield and price risk on conversion from conventional to organic farming. Australian Journal of Agricultural and Resource Economics, 53: 393-411.

BELLON, S. and PENVERN, S. 2014. Organic Farming as a Prototype for Sustainable Agricultures. London: Springer Science \& Business Media.

BREKKE, K. A., KVERNDOKK, S. and NYBORG, K. 2003. An economic model of moral motivation. Journal of Public Economics, 87(9-10): 1967-1983.

BURTON, M., RIGBY, D. and YOUNG, T. 1999. Analysis of the determinants of adoption of organic horticultural techniques in the UK. Journal of Agricultural Economics 50(1): 47-63.

FLATEN, O., LIEN, G., KOESLING, M. et al. 2010. Norwegian farmers ceasing certified organic production: haracteristics and reasons. Journal of Environmental Management, 91: 2717-2726.

GREENE, C., DIMITRI, C., LIN, B. H. et al. 2009. Emerging issues in the U.S. organic industry, economic information bulletin. USDA Economic Research Service.

HEIMLER D., ISOLANI, L., VIGNOLINI, P. et al. 2009. Polyphenol content and antiradical activity of Cichorium intybus L. from biodynamic and conventional farming. Food Chemistry, 3: 765-770.

HEIMLER, D., VIGNOLINI, P., ARTAIOL, P. et al. 2011. Conventional, organic and biodynamic farming: differences in polyphenol content and antioxidant activity of Batavia lettuce. J Sci Food Agric, 91(3): 551-556.

CHOUINARD, H., PATERSON, T., WANDSCHNEIDER, P. et al. 2008. Will farmers trade profits for stewardship? Heterogeneous motivations for farm practice selection. Land Economics, 84(1): 66-82.

IFOAM. 2016. IFOAM [Online]. Available at: http://www.ifoam.org/en/search?find=member [Accessed: 2016, December 18].

JULA, W. H. and LERNOUD, J. 2017. The World of Organic Agriculture. Statistic and Emerging Trends 2017. Bonn: Research Institure of Organic Agriculture (FiBL), Frick, and IFOAM - Organics International.

KERSELAERS, E., DECOCK, L., LAUWERS, L. et al. 2007. Modelling farm-level economic potential for conversion to organic farming. Agricultural Systems, 94: 671-682.

KHALEDI, M., WESEEN, S., SAWYER, E. et al. 2010. Factors Influencing Partial and Complete Adoption of Organic Farming Practices in Saskatchewan, Canada. Canadian Journal of Agricultural Economics-Revue Canadienne D Agroeconomie, 58: 37-56.

KOMOROWSKA, D. 2014. Development of organic production and organic food market in Europe. Acta Scientiarum Polonorum. Oeconomia, 13(4): 91-101. 
KROUPOVÁ,Z. and MALÝ,M.2010. Analysis of Agriculture Subsidy Policy Tools - Aplication of production function. Politická ekonomie, 58(6): 774-794.

KUMINOFF, N. V. and WOSSINK, A. 2010. Why isn't more US farmland organic? Journal of Agricultural Economics, 61: 240-258.

LAMPKIN, N. H. and PADEL, S. 1994. The economics of organic farming. An international perspective. Wallingford: CAB International.

LIEBMAN, M., MOHLER, C. L., STAVER, C. P. 2001. Ecological management of agricultural weeds. $1^{\text {st }}$ Edition. Cambridge: Cambridge University Press.

MALÁ, Z. 2011. Efficiency analysis of Czech organic agriculture, Economics and Management, 1: 14-28.

MONDELAERS, K., AERTSENS, J. and VAN HUYLENBROECK, G. 2009. A meta-analysis of the differences in environmental impacts between organic and conventional farming. British Food Journal, 111: 1098-1119.

MZOUGHI, N. 2011. Farmers adoption of integrated crop protection and organic farming: Do moral and social concerns matter? Ecological Economics, 70: 1536-1545.

MINISTRY OF AGRICULTURE. 2015. Zpráva o trhu s biopotravinami 2014. Ministerstvo zemédèlství. [Online]. Available at: http://eagri.cz/public/web/mze/ministerstvo-zemedelstvi/statistika/ekologickezemedelstvi/zprava-o-trhu-s-biopotravinami-2014.html [Accessed: 2017, January 11].

MINISTRY OF AGRICULTURE. 2015. Ročenka ekologického zemědělství 2015. Ministerstvo zemédèlství. [Online]. Available at: http://eagri.cz/public/web/mze/ministerstvo-zemedelstvi/statistika/ekologickezemedelstvi/rocenka-ekologickeho-zemedelstvi-2015.html [Accessed: 2016, November 17].

PECHROVÁ, M. 2014. Determinants of the Farmers' Conversion to Organic and Biodynamic Agriculture. Agris On-Line Papers in Economics $\sigma$ Informatics, 6(4): 113-120.

PIMENTEL, D., HEPPERLY, P., HANSON, J., et al. 2005. Environmental, Energetic,and Economic Comparisons of Organic and Conventional Farming Systems. BioScience, 55(7): 573-582.

PRO-BIO. 2016. PRO-BIO Svaz ekologických zemédèlcui. [Online]. Available at: www.PRO-BIO.cz [Accessed: 2016, December 13].

REMBIALKOWSKA, E. 2007. Quality of plant products from organic agriculture. Journal of the Science of Food and Agriculture, 87(5): 2757-2762.

SPOOLDER, H. A. M. 2007. Animal welfare in organic farming systems. Journal of the Science of Food and Agriculture, 87: 2741-2746.

STANCIU, S. 2008. Assessing environmental integration in EU agriculture policy, Lucrări ştiințifice, 40(3): 337-342.

STEINER, R. 2004. Agriculture Course: The Birth of Biodynamic Method. Forest Row: Rudolf Steiner Press.

ŠEJNOHOVÁ, H., RÂDLOVÁ, L. and PETERKOVÁ, J. 2014. Statistická šetření ekologického Zemědělství Základní statistické údaje, TÚ 4212/2015, No,2, UZEI, 2015. eAgri. [Online]. Available at: http://eagri.cz/ public/web/file/433187/Statisticka_setreni_ekologickeho_zemedelstvi_2014 finalverze.pdf [Accessed: 2017, January 10].

TUOMISTO, H. L., HODGE, I. D., RIORDAN, P., et al. 2012. Does organic farming reduce environmental impacts? A meta-analysis of European research, Journal of Environmental Management, 112: 309-320.

VETTER, H., ABERCRON, M., BISCHOFF, R., et al. 1987 Qualität pfanzlicher Nahrungsmittel - "alternativ" und "modern" im Vergleich, Teil III. AID-Schriftenreihe Verbraucherdienst, 3100: 1-3.

WENDELL, B. and HOWARD, A. 2010. The Soil and Health. The University Press of Kentucky

WOESE, K., LANGE, D., BOESS, C., et al. 1977. A comparison of organically and conventionally grown foods: results of a review of the relevant literature. J Sci Food Agric, 74: 281-293.

ZÍDEK, T. 1999. Postavení ekologického zemédélství v České republice a jeho vývoj od roku 1990. In: 10 let ekologického zemédèlství v České republice. Praha: Česká zemědělská univerzita.

Contact information

Hana Stojanová: hana.stojanova@mendelu.cz

Veronika Blašková: veronika.blaskova@mendelu.cz

Michaela Lněničková: michaela.lnenickova@mendelu.cz 